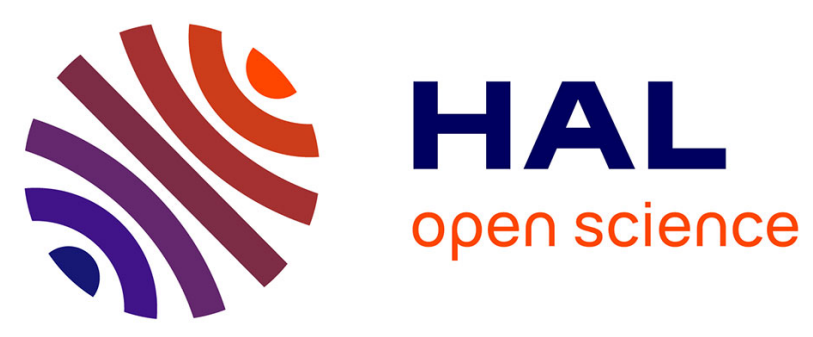

\title{
In vivo silencing of Reptin blocks the progression of human hepatocellular carcinoma in xenografts and is associated with replicative senescence.
}

Ludovic Ménard, Danièle Taras, Aude Grigoletto, Valérie Haurie, Alexandra Nicou, Nathalie Dugot-Senant, Pierre Costet, Benoît Rousseau, Jean Rosenbaum

\section{To cite this version:}

Ludovic Ménard, Danièle Taras, Aude Grigoletto, Valérie Haurie, Alexandra Nicou, et al.. In vivo silencing of Reptin blocks the progression of human hepatocellular carcinoma in xenografts and is associated with replicative senescence.: Reptin silencing blocks liver cancer progression. Journal of Hepatology, 2010, 52 (5), pp.681-9. 10.1016/j.jhep.2009.12.029 . inserm-00449372

\section{HAL Id: inserm-00449372 https://www.hal.inserm.fr/inserm-00449372}

Submitted on 21 Jan 2010

HAL is a multi-disciplinary open access archive for the deposit and dissemination of scientific research documents, whether they are published or not. The documents may come from teaching and research institutions in France or abroad, or from public or private research centers.
L'archive ouverte pluridisciplinaire $\mathbf{H A L}$, est destinée au dépôt et à la diffusion de documents scientifiques de niveau recherche, publiés ou non, émanant des établissements d'enseignement et de recherche français ou étrangers, des laboratoires publics ou privés. 
In vivo silencing of Reptin blocks the progression of human hepatocellular carcinoma in xenografts and is associated with replicative senescence

Ludovic Ménard ${ }^{1,2^{*}}$, Danièle Taras ${ }^{1,2^{*}}$, Aude Grigoletto ${ }^{1,2}$, Valérie Haurie ${ }^{1,2}$, Alexandra Nicou $^{1,2}$, Nathalie Dugot-Senant ${ }^{2}$, Pierre Costet $^{3}$, Benoît Rousseau ${ }^{4}$, and Jean Rosenbaum ${ }^{1,2}$

Authors' affiliations : ${ }^{1}$ INSERM, U889; Université de Bordeaux, F-33076 Bordeaux, France; ${ }^{2}$ Université de Bordeaux, Institut Fédératif de Recherches 66, F-33076 Bordeaux, France; ${ }^{3}$ Université de Bordeaux, Animalerie spécialisée, F-33076 Bordeaux, France; ${ }^{4}$ Université de Bordeaux, Animalerie A2, F-33076 Bordeaux, France

Note : * LM and DT contributed equally to this work

Short title : Reptin silencing blocks liver cancer progression

Corresponding author : Jean Rosenbaum : INSERM U889, Université Victor Segalen Bordeaux 2, 146 rue Léo Saignat, 33076 Bordeaux cedex, France. Phone : +33 5557571 594; Fax : +33 556514077 ; E-mail : jean.rosenbaum@gref.u-bordeaux2.fr

Electronic word count : 3300

Number of figures : 5 


\begin{abstract}
Background/Aims. We showed that Reptin is overexpressed in hepatocellular carcinoma (HCC). In vitro depletion of Reptin with siRNAs led to HCC cell growth arrest and apoptosis. We asked whether in vivo targeting of Reptin in established tumors had a therapeutic effect. Methods. We used lentiviral vectors to construct $\mathrm{HuH7}$ and $\mathrm{Hep} 3 \mathrm{~B}$ cell lines with doxycycline (Dox)-dependent expression of Reptin (R2) or control shRNA (GL2). Cells were injected subcutaneously into immunodeficient mice and Dox was given when tumors reached a volume of $250 \mathrm{~mm}^{3}$.

Results. In vitro, the growth of GL2-Dox, GL2+Dox and R2-Dox cells was undistinguishable whereas that of R2+Dox cells stopped 4 days after Dox treatment. Growth decrease was associated with increased apoptosis, and evidence of replicative senescence, as shown by staining for acid $\beta$-galactosidase and the presence of senescence-associated heterochromatin foci. In xenografted mice, R2+Dox tumor growth stagnated or even regressed with prolonged treatment, in contrast with the GL2-Dox, GL2+Dox and R2-Dox tumors that progressed steadily. The blockage of tumor progression was associated with induction of senescence and reduced cell proliferation.
\end{abstract}

Conclusions. In vivo Reptin depletion leads to tumor growth arrest. Reptin may prove a valuable target in HCC.

Key words : liver cancer, apoptosis, senescence, shRNA, doxycycline 


\section{INTRODUCTION}

Hepatocellular carcinoma is the fifth most common cause of cancer in the world and the third most common cause of cancer mortality (1). The identification of new therapeutic targets is essential in order to improve HCC therapy. Through a comparative study of the proteome of HCC with that of the peri-tumor liver, we identified the deregulation of a number of proteins (2), and especially the overexpression of RuvBL2/Reptin (3). Reptin is also known as TIP49b (4), TIP48 (5), Reptin52 (6), Rvb2 (7), TAP54 3 (8), and ECP-51 (9). It belongs to the AAA+ family of ATPases (reviewed in $(10,11)$ ) and shows a limited homology to the bacterial RuvB ATP-dependent DNA helicase. Reptin is required for the growth and viability of yeast (12) and is essential for the normal development of Zebrafish (13), Xenopus (14), and Drosophila (15). Reptin is found in several high-molecular-weight complexes involved in chromatin remodeling, transcriptional regulation or DNA damage repair $(7,8,16)$. It also interacts with proteins playing key roles in oncogenesis, such as $\beta$-catenin $(6,17)$, c-Myc (5), and telomerase (18).

We showed that Reptin overexpression was found in $75 \%$ of HCC and was associated with a poor prognosis (3). We also found that in vitro depletion of Reptin with siRNAs led to tumor cell growth arrest and to apoptotic cell death, whereas Reptin overexpression increased tumorigenicity in xenografts experiments.

Although these findings strongly suggest that Reptin may be a target in $\mathrm{HCC}$, they require in vivo validation. For instance, tumor cells in a three dimensional setting like within tumors are more resistant to apoptosis and to chemotherapeutic drugs than when cultured in vitro in two dimensions (reviewed in $(19,20)$ ), and might also respond differently to Reptin depletion. In this study, we thus used a conditional shRNA expression model that allows switching off 
Reptin expression in vivo within already established tumors, thus mimicking a therapeutic setting.

\section{MATERIALS AND METHODS}

\section{Construction of cell lines with a conditional expression of Reptin shRNA}

We previously generated $\mathrm{HuH7}$ cells with conditional, doxycyclin-dependent, expression of a Reptin shRNA (21). Hep3B human HCC cells were similarly engineered. The Reptin shRNA sequence was the R2 sequence previously described (3). As a control, we used a shRNA targeting Firefly luciferase (GL2). shRNA sequences are shown in Table 1.

\section{Transient transfection of small interfering RNA (siRNA)}

The siR1 and siR2 siRNAs targeting Reptin mRNA were described (3). They were bought from Eurogentec (Searing, Belgium) and transfected using Lipofectamine (Invitrogen, Cergy Pontoise, France) at a final concentration of $125 \mathrm{nM}$. As a control, we used the GL2 sequence targeting luciferase.

\section{Western Blot}

Samples were prepared in a radioimmunoprecipitation buffer (22). Protein concentration was measured with a Bio-Rad assay (Marnes-la-Coquette, France). Samples were analyzed by western blot with a Reptin mouse monoclonal antibody (BD Biosciences Pharmingen, Erembodegem, Belgium) and an anti- $\beta$-actin antibody for normalization. The blots were incubated with a secondary fluorescent antibody and signals were acquired and quantified with the Odyssey system (Li-Cor Biosciences, Lincoln, NE). 


\section{Cell proliferation}

Cells were seeded at a density of 50000 per well in 12-well plates. Adherent cells were counted at various times with a Coulter counter (Beckman Coulter, Villepinte, France) in duplicate wells.

\section{Apoptosis assays}

We quantified caspase 3 activity with a colorimetric assay as described by the manufacturer (Chemicon, Temecula, CA).

TUNEL assay was performed with the In Situ Cell Death Detection kit (Roche, Meylan, France).

\section{Senescence assays}

For evaluating acid $\beta$-galactosidase activity, cells were trypsinized and equivalent numbers were deposited on glass slides using a Shandon cytospin (Thermo Scientific, Waltham, MA). $\beta$-galactosidase activity was measured using a kit from Cell Signaling Technology (Danvers, MA). The same protocol was used on tissue cryosections from xenografts.

For detection of senescence-associated heterochromatin foci (SAHF) (23), cells were fixed with methanol at $-20^{\circ} \mathrm{C}$ for 10 minutes, DNA was stained with DAPI (Sigma, $0.5 \mu \mathrm{g} / \mathrm{ml}$ ) and cells were examined under a Zeiss Axioplan microscope.

Telomerase activity was evaluated using the Quantitative Telomerase Detection Kit (US Biomax) following instructions from the supplier.

\section{$R T-Q P C R$}

Total RNA was extracted from cultured cells with Trizol (Invitrogen, Cergy Pontoise, France). Frozen xenografts samples were first disrupted in Trizol with a bead grinder (Retsch, 
Eragny sur Oise, France). Two micrograms of RNA were reverse-transcribed with Superscript III (Invitrogen) and $100 \mathrm{ng}$ of random hexamers (Roche, Meylan, France). Five (Reptin) or $2.5 \mu \mathrm{l}$ (RLP0) of a 50-fold dilution of cDNA were used as template. PCR mixes were made so that each $25 \mu$ reaction contained $12.5 \mu 1$ of iQ Sybr Green Supermix (Bio-Rad) with $200 \mathrm{nM}$ sense and antisense gene primers and diluted cDNA template. Reactions were run on the Mx4000 Multiplex Quantitative PCR system (Stratagene, La Jolla, CA). Sequences of primers are in Table 2. For use in xenografted tumors, they were designed, and verified, to be humanspecific.

Data analysis was performed with Mx4000 software (version 4.2, Stratagene). Gene expression results were first normalized to internal control RLP0 or $\beta$-actin. Relative levels of expression were quantified by the calculation of $2^{-\Delta \Delta \mathrm{Ct}}(24)$. The results were expressed as a ratio with respect to the expression level in GL2 cells without Dox.

\section{Xenografts}

Animals used were either non-obese diabetic-severe combined immunodeficiency mutation (NOD-SCID) (25) or NOD/SCID/ $/ \gamma_{c}{ }^{\text {null }}$ (NOG) (26) mice. Mice aged 9 to 15 weeks were used. The study was performed in accordance with the European Community Standards on the Care and Use of Laboratory Animals. Mice were injected subcutaneously with either $4.10^{6} \mathrm{HuH} 7$ (mixed with an equal volume of Matrigel, Becton Dickinson), or $3.10^{6}$ Hep3B cells in the flank. Tumor size was monitored with calipers. Tumor volume was estimated as $\left(D^{2} \times d\right) / 2$, where $D$ is the large diameter and $d$ is the small diameter of the tumor. At the end of the experiment, tumors were divided into parts snap-frozen in liquid nitrogen, frozen in liquid nitrogen-cooled isopentane, or fixed in $10 \%$ neutral formalin.

\section{Immunohistochemistry}


Reptin was detected as described (3), except that the antibody was diluted 1/150. Ki67 and activated caspase 3 were detected using antibodies from Dako (M7240, 1/75) and R\&D Systems (H1009, 1/200), respectively. The number of KI67-positive cells was measured relative to the total number of cells in 5 random fields examined under the $63 \mathrm{X}$ objective.

\section{Statistical Analysis}

Differences between means were assessed with analysis of variance (ANOVA). A $P$ value less than 0.05 was considered significant.

\section{RESULTS}

\section{Expression of a siRNA-resistant Reptin rescues the cell growth phenotype}

We showed that transient transfection of 2 different siRNAs against Reptin reduced cell proliferation whereas a control siRNA had no effect (3). Before conducting in vivo experiments, we performed an additional control in order to rule out possible off-target effects. We generated a Reptin cDNA harboring silent mutations in the siRNA targeting sequence that makes the mRNA insensitive to this siRNA (21). Fig. 1B shows that transduced cells express both endogenous Reptin and the Flag-tagged form. Transfection with siR1 leads as expected to a major decrease of both endogenous and Flag-tagged Reptin. On the other hand, transfection with siR2 affects only endogenous Reptin, but does not decrease the levels of siR2-resistant, Flag-tagged Reptin. Actually, in cells transfected with siR2, despite the decrease in endogenous Reptin, the total amount of Reptin was not different from that of control cells (Fig. 1C), because of an increased amount of Flag-tagged Reptin (Fig. 1B, compare lanes 3 or 7 with lanes 1-2 or 5-6, respectively).

We then assessed whether the siR2-resistant Flag-tagged Reptin was able to rescue the growth phenotype. Transient transfection of siR1 induced as expected a profound reduction in cell 
numbers whereas the growth of cells transfected with siR2 was indistinguishable from that of non transfected cells or cells transfected with the control siRNA (Fig. 1D).

Altogether, these data show that the effects of siR2 on cell growth are sequence-specific.

\section{Conditional expression of Reptin shRNA}

We used a conditional shRNA expression system (27) based on the expression of the tTR protein fused to the KRAB domain of human Kox1 (28). KRAB is a transcriptional repression domain that represses all three RNA polymerases (29). In the absence of Dox, tTR-KRAB binds specifically to tetO sequence and suppresses the activity of the nearby promoter. In the presence of Dox, tTR-KRAB does not bind the tetO sequence, thus allowing gene expression (28). Here, shRNA sequences are under the control of the polymerase III-dependent H1 promoter itself under the control of the tetO sequence. A cassette containing the GFP reporter gene under the control of the ubiquitously active mammalian EF1 $\alpha$ promoter is located upstream the tetO sequence. Consequently, GFP expression is also under the control of tTRKRAB.

We first checked that the cell lines expressed the transgenes in a Dox-dependent manner. No cells detectably expressed GFP in the absence of Dox, indicating the tightness of the transcriptional repression (Fig 2A). With $0.002 \mu \mathrm{g} / \mathrm{ml}$ Dox, 31 (GL2) or $46 \%$ (R2) of cells were GFP-positive, whereas up to $90 \%$ of cells expressed detectable amounts of GFP with $0.016 \mu \mathrm{g} / \mathrm{ml}$ of Dox or higher. This indicates that a vast majority of cells have integrated the lentiviral genome and consequently GL2 or R2 shRNA.

We then used quantitative RT-PCR to measure Reptin transcript levels. At 72 hours after Dox treatment, as compared to untreated GL2 cells, Reptin mRNA levels were reduced to $28.2 \% \pm$ $20.2 \%$ in R2 cells versus $102.6 \% \pm 6.0 \%$ in R2 cells not treated with Dox $(n=3, p<0.01)$ (Fig 2B). There was no difference between Reptin mRNA levels in GL2+Dox versus GL2-Dox. 
Finally, we measured Reptin protein expression by western blot (Fig. 2C). The results were parallel to those of GFP expression, with a maximal decrease of more than $80 \%$ with concentrations $\geq 0.016 \mu \mathrm{g} / \mathrm{ml}$ Dox. In the GL2 cell line, no change in Reptin expression was observed with or without Dox. In the following experiments, we used the concentration of $0.016 \mu \mathrm{g} / \mathrm{ml}$ Dox.

We noticed that the Reptin/actin ratio increased over time in GL2 cells, in the absence or in the presence of Dox (Fig 2D), as well as in un-transduced cells. This was not observed in the R2 cell line grown without Dox, which may indicate a small leak in the shRNA transcriptional control that was not apparent at shorter time points. However, Dox treatment of R2 cells induced major changes with a $40 \%$ decrease in Reptin protein observed already after one day. The decrease was maximum 4 days after treatment, reached almost $100 \%$ and was stable as long as Dox was maintained.

Reptin silencing induces a decrease in cell growth and results in apoptosis and senescence

The growth curve over 6 days of GL2-Dox, GL2+Dox and R2-Dox cells was undistinguishable (Fig. 3A). In contrast, the growth of R2+Dox cells was already detectably slowed after 4 days of Dox treatment, and was greatly reduced thereafter. For instance, whereas the number of R2-Dox cells increased by $74.3 \pm 20.1 \%$ between Day 5 and Day 6, that of R2+Dox cells increased by only $15.8 \pm 3.9 \%$. The differences in cell numbers at Day 6 were highly significant $(\mathrm{p}<0.0001$; Fig 3A). Similar results were obtained with the Hep3B cell lines (Fig. 3B). 
Consistent with our previous study (3), the decrease in cell growth was due in part to increased apoptosis. Indeed, caspase 3 activity was significantly increased in R2+Dox cells in comparison to control cells ( $\mathrm{p}<0.001$; Fig. 3C).

In addition, we also tested whether Reptin knock-down resulted in increased cell senescence. Acid $\beta$-galactosidase activity was indeed found in a much larger number of cells in the R2+Dox condition than in the 3 other groups (Fig. 3D). Most positively stained cells also exhibited a larger size than other cells, an additional argument for a senescent phenotype. Moreover, the staining of nuclear DNA showed characteristic SAHF in nuclei of R2+Dox cells (Fig 3E). Lastly, telomerase activity was reduced in R2+Dox as compared to R2-Dox cells (4.7 and 6.9 fold in 2 separate experiments conducted in triplicate in cells grown for 5 days with or without Dox).

\section{Conditional silencing of Reptin reduces tumor growth in xenografts.}

To test if Reptin expression is necessary for tumor growth in vivo, we inoculated NOD-SCID mice (30) with the GL2 or R2 HuH7 cell lines. When the tumor volume reached $250 \mathrm{~mm}^{3}$, mice were randomly assigned to receive either Dox $(2 \mathrm{mg} / \mathrm{mL}$ in drinking water with $5 \%$ sucrose), or only sucrose.

Starting from Day 4 after administration of Dox, the mean tumor volume in R2+Dox animals did not progress until the end of the experiment, in contrast with the R2-Dox animals in which it progressed steadily ( $\mathrm{p}<0.0001$ ) (Fig 4A). The decrease in tumor growth of R2+Dox animals was not due only to the Dox treatment as evidenced by the similar progression of tumors in GL2-Dox and GL2+Dox animals. Similar results were obtained with xenografts of Hep3B cells. In that case, whereas animals from all three control groups had to be sacrificed for ethical reasons because of progressive tumor growth, R2+Dox tumors soon stopped 
growing and some eventually completely regressed when treatment was further prolonged (Fig. 4B).

We used immunohistochemistry in explanted tumors to confirm that reduced tumor growth correlated with silencing of Reptin expression, Reptin staining was intense in tumor cells from GL2-Dox, GL2+Dox or R2-Dox groups, whereas it was almost absent in R2+Dox tumors (Fig. 4C).

\section{Mechanisms of anti-tumor effects in vivo}

Because explanted tumors at the end of the above experiment were very much remodeled and exhibited large areas of necrosis, it was not feasible to quantify accurately cell proliferation, apoptosis or senescence. We thus repeated the experiment with $\mathrm{HuH7}$ cells in another series of mice that were sacrificed after only 8 days on Dox treatment. This experiment again demonstrated the striking effect of Reptin silencing, leading to a complete arrest in tumor progression (Fig. 5A). RT-PCR confirmed the drastic decrease in Reptin transcripts in R2+Dox tumors (Fig. 5B). Reptin staining in explanted tumors was also considerably decreased in R2+Dox tumors (Fig. 5C) where only some nuclear staining persisted (See inset at higher magnification. From in vitro experiments, we noticed that shRNAs depleted more rapidly cytoplasmic than nuclear Reptin, not shown).

Control tumors (GL2 \pm Dox, R2-Dox) exhibited a massive Ki67 staining, which was significantly reduced in R2 + Dox tumors (Fig. 5C-D, p = 0.0038).

The mean number of TUNEL-positive cells in R2+Dox tumors was $6.9 \pm 1.6$ per microscopic field, not significantly different from that in R2-Dox tumors $(4.8 \pm 1.9)$. Immunostaining for activated caspase 3 did not either reveal differences between groups (not shown). In addition, Bad and Bak mRNA levels in explanted tumors were not increased in R2+Dox tumors (Fig. $5 \mathrm{E})$. 
Staining for acid $\beta$-galactosidase activity was scarcely seen in control tumors whereas every R2+Dox tumor exhibited many positive cells, often in foci (Fig. 5C). In addition DAPI staining showed a large number of cells with SAHF in R2+Dox tumor sections (Fig. 5C). The number of cells with SAHF counted in 3 random microscopic fields was $29.0 \pm 8.7$ and $1.8 \pm$ 0.2/field in R2+Dox and R2-Dox tumors, respectively $(\mathrm{p}=0.03, \mathrm{n}=4)$.

\section{DISCUSSION}

We previously showed that overexpression of Reptin was found in the vast majority of HCC and correlated with a poor prognosis. In addition, experimental evidence suggested that Reptin played a role in hepatocarcinogenesis and was a potential therapeutic target (3). It remained however to be shown that targeting Reptin in established tumors had a therapeutic effect.

The constitutive expression of shRNA is commonly used for the study of the loss of function of a protein, but it is a major problem when the targeted gene is essential for the survival of cells. In order to circumvent this problem, several inducible shRNA systems have been developed, relying either on inducers such as tetracycline or its derivatives $(27,31,32)$, or on the Cre-LoxP system (33). To date, however only a few recent studies have used these tools to demonstrate the role of a protein in tumor progression, especially in a therapeutic-type situation, i.e., when tumors were already established (34-37).

Here, we studied the impact of a decreased expression of Reptin on tumor growth in a xenograft model in mice. We first took great care to ensure of the specificity of the siRNA targeting sequence. In addition to previous control experiments (3), we thus used a rescue strategy, and we used a luciferase siRNA as an additional control. Altogether, these experiments allowed to conclude with a high level of confidence that the effects of the siR2 targeting sequence were very specific according to published guidelines (38). 
For in vivo experiments, we engineered $\mathrm{HuH7}$ and Hep3B human $\mathrm{HCC}$ cell lines conditionally expressing Reptin shRNA in a Dox-dependent manner (27). In vitro studies showed that expression of the Reptin shRNA recapitulated our findings with transient transfection of siRNA, like cell growth inhibition and increased apoptosis (3). In addition, we made the new finding that Reptin silencing also increased the occurrence of cell senescence. Reptin participates in the TIP60 complex together with p400, a member of the SWI2/SNF2 chromatin-remodeling family (8). Chan et al. observed that p400 or Reptin knock-down resulted in cell senescence in fibroblasts (39). This was not tested in tumor cells. However, they found that p400 knock-down did not induce senescence in cells with mutated p53. HuH7 have one deleted p53 allele and a codon 220 mutation in the other, resulting in a stabilized protein, albeit with a loss of transcriptional activity (40). Thus p53 inactivation does not preclude the induction of senescence by Reptin depletion, suggesting that its mechanism may differ from that due to $\mathrm{p} 400$ depletion. The induction of senescence with Reptin extinction is in agreement with the recent demonstration that Reptin is required for telomerase activity (18), a finding that was also observed in our model.

We injected transduced cell lines to mice. When tumors reached a predefined volume, we induced the transcription of shRNAs by administering Dox. This led to a large decrease in Reptin expression in vivo, only in R2+Dox animals. Reptin depletion was associated with a striking inhibition of the tumor growth. Indeed, the progression of these tumors almost completely stopped a few days following Dox treatment. In the case of Hep3B-derived tumors, a more prolonged treatment even led to a complete regression of some tumors. Although apoptosis was clearly detectable in $\mathrm{HuH7}$ cells in vitro 6 days following Reptin shRNA induction, none was observed in vivo after 8 days even though Reptin was effectively silenced and tumor growth had already stopped. It is possible that in vivo, tumor cells are 
somehow protected from apoptosis due to Reptin depletion because of the three-dimensional architecture and of the presence of the tumor stroma that conveys protective signals $(19,20)$. However, reduced tumor progression was associated with reduced cell proliferation and induction of senescence. We suggest that Reptin silencing, likely through inhibition of telomerase activity, induces cell senescence resulting in inhibition of cell proliferation. Because Hep3B tumors eventually regressed, it is however likely that apoptosis occurred secondarily.

Our results may have therapeutic relevance because, even though using siRNAs for the treatment of cancer is still a remote prospect, targeting the ATPase activity of Reptin with drugs may be accessible. Circumstantial evidence suggests that this enzymatic activity is required for oncogenesis. Indeed, mutations that abolish ATPase activity of the yeast homologue of Reptin suppresses the growth of the yeast $S$. cerevisiae $(4,12)$, whereas an ATPase activating mutation has growth-promoting effects in the Zebrafish (41). In addition, ATPase deficient mutants of the related protein Pontin impair the transforming activity of $\beta$ catenin (42) or of c-myc (5).

\section{ACKNOWLEDGMENTS}

Supported by grants to JR from Institut National du Cancer, Association pour la Recherche sur le Cancer, Agence Nationale pour la Recherche sur le SIDA et les Hépatites Virales, Ligue Nationale Contre le Cancer and Conseil Régional d'Aquitaine. VH was supported by a fellowship from Agence Nationale pour la Recherche sur le SIDA et les Hépatites Virales, and AN by a fellowship from Institut National du Cancer.

\section{REFERENCES}

1. Parkin DM. Global cancer statistics in the year 2000. Lancet Oncol 2001;2:533-543. 
2. Blanc J, Lalanne C, Plomion C, Schmitter J, Bathany K, Gion J, et al. Proteomic analysis of differentially expressed proteins in hepatocellular carcinoma developed in patients with chronic viral hepatitis C. Proteomics 2005;5:3778-3789.

3. Rousseau B, Menard L, Haurie V, Taras D, Blanc J, Moreau-Gaudry F, et al. Overexpression and role of the ATPase and putative DNA helicase RuvB-like 2 in human hepatocellular carcinoma. Hepatology 2007;46:1108-1118.

4. Kanemaki M, Kurokawa Y, Matsu-ura T, Makino Y, Masani A, Okazaki K, et al. TIP49b, a new RuvB-like DNA helicase, is included in a complex together with another RuvB-like DNA helicase, TIP49a. J Biol Chem 1999;274:22437-22444.

5. Wood MA, McMahon SB, Cole MD. An ATPase/helicase complex is an essential cofactor for oncogenic transformation by c-Myc. Mol Cell 2000;5:321-330.

6. Bauer A, Chauvet S, Huber O, Usseglio F, Rothbacher U, Aragnol D, et al. Pontin52 and reptin52 function as antagonistic regulators of beta-catenin signalling activity. Embo $\mathrm{J}$ 2000;19:6121-6130.

7. Shen X, Mizuguchi G, Hamiche A, Wu C. A chromatin remodelling complex involved in transcription and DNA processing. Nature 2000;406:541-544.

8. Ikura T, Ogryzko VV, Grigoriev M, Groisman R, Wang J, Horikoshi M, et al. Involvement of the TIP60 histone acetylase complex in DNA repair and apoptosis. Cell 2000;102:463-473.

9. Salzer U, Kubicek M, Prohaska R. Isolation, molecular characterization, and tissuespecific expression of ECP-51 and ECP-54 (TIP49), two homologous, interacting erythroid cytosolic proteins. Biochim Biophys Acta 1999;1446:365-370.

10. Ammelburg M, Frickey T, Lupas AN. Classification of AAA+ proteins. J Struct Biol 2006;156:2-11. 
11. Iyer LM, Leipe DD, Koonin EV, Aravind L. Evolutionary history and higher order classification of AAA+ ATPases. J Struct Biol 2004;146:11-31.

12. Jonsson ZO, Dhar SK, Narlikar GJ, Auty R, Wagle N, Pellman D, et al. Rvb1p and Rvb2p are essential components of a chromatin remodeling complex that regulates transcription of over 5\% of yeast genes. J Biol Chem 2001;276:16279-16288.

13. Amsterdam A, Nissen RM, Sun Z, Swindell EC, Farrington S, Hopkins N. Identification of 315 genes essential for early zebrafish development. Proc Natl Acad Sci U S A 2004;101:12792-12797.

14. Etard C, Gradl D, Kunz M, Eilers M, Wedlich D. Pontin and Reptin regulate cell proliferation in early Xenopus embryos in collaboration with c-Myc and Miz-1. Mech Dev 2005;122:545-556.

15. Bellosta P, Hulf T, Balla Diop S, Usseglio F, Pradel J, Aragnol D, et al. Myc interacts genetically with Tip48/Reptin and Tip49/Pontin to control growth and proliferation during Drosophila development. Proc Natl Acad Sci U S A 2005;102:11799-11804.

16. Jin J, Cai Y, Yao T, Gottschalk AJ, Florens L, Swanson SK, et al. A mammalian chromatin remodeling complex with similarities to the yeast INO80 complex. J Biol Chem 2005;280:41207-41212.

17. Kim JH, Kim B, Cai L, Choi HJ, Ohgi KA, Tran C, et al. Transcriptional regulation of a metastasis suppressor gene by Tip60 and beta-catenin complexes. Nature 2005;434:921926.

18. Venteicher AS, Meng Z, Mason PJ, Veenstra TD, Artandi SE. Identification of ATPases pontin and reptin as telomerase components essential for holoenzyme assembly. Cell 2008;132:945-957.

19. Schmeichel KL, Bissell MJ. Modeling tissue-specific signaling and organ function in three dimensions. J Cell Sci 2003;116:2377-2388. 
20. Mueller-Klieser W. Tumor biology and experimental therapeutics. Crit Rev Oncol Hematol 2000;36:123-139.

21. Haurie V, Ménard L, Nicou A, Touriol C, Metzler P, Fernandez J, et al. Adenosine triphosphatase pontin is overexpressed in hepatocellular carcinoma and coregulated with reptin through a new posttranslational mechanism. Hepatology 2009;50:1871-1883.

22. Neaud V, Gillibert Duplantier J, Mazzocco C, Kisiel W, Rosenbaum J. Thrombin Upregulates Tissue Factor Pathway Inhibitor-2 Synthesis through a Cyclooxygenase-2dependent, Epidermal Growth Factor Receptor-independent Mechanism. J Biol Chem 2004;279:5200-5206.

23. Adams PD. Remodeling of chromatin structure in senescent cells and its potential impact on tumor suppression and aging. Gene 2007;397:84-93.

24. Livak KJ, Schmittgen TD. Analysis of relative gene expression data using real-time quantitative PCR and the 2(-Delta Delta C(T)) Method. Methods 2001;25:402-408.

25. Greiner DL, Shultz LD, Yates J, Appel MC, Perdrizet G, Hesselton RM, et al. Improved engraftment of human spleen cells in NOD/LtSz-scid/scid mice as compared with C.B-17-scid/scid mice. Am J Pathol 1995;146:888-902.

26. Ito M, Hiramatsu H, Kobayashi K, Suzue K, Kawahata M, Hioki K, et al. NOD/SCID/gamma(c)(null) mouse: an excellent recipient mouse model for engraftment of human cells. Blood 2002;100:3175-3182.

27. Wiznerowicz M, Trono D. Conditional suppression of cellular genes: lentivirus vectormediated drug-inducible RNA interference. J Virol 2003;77:8957-8961.

28. Deuschle U, Meyer WK, Thiesen HJ. Tetracycline-reversible silencing of eukaryotic promoters. Mol Cell Biol 1995;15:1907-1914.

29. Urrutia R. KRAB-containing zinc-finger repressor proteins. Genome Biol 2003;4:231. 
30. Prochazka M, Gaskins HR, Shultz LD, Leiter EH. The nonobese diabetic scid mouse: model for spontaneous thymomagenesis associated with immunodeficiency. Proc Natl Acad Sci U S A 1992;89:3290-3294.

31. Matsukura S, Jones PA, Takai D. Establishment of conditional vectors for hairpin siRNA knockdowns. Nucleic Acids Res 2003;31:e77.

32. Matthess Y, Kappel S, Spankuch B, Zimmer B, Kaufmann M, Strebhardt K. Conditional inhibition of cancer cell proliferation by tetracycline-responsive, $\mathrm{H} 1$ promoterdriven silencing of PLK1. Oncogene 2005;24:2973-2980.

33. Ventura A, Meissner A, Dillon CP, McManus M, Sharp PA, Van Parijs L, et al. Crelox-regulated conditional RNA interference from transgenes. Proc Natl Acad Sci U S A 2004;101:10380-10385.

34. Cheng H, Snoek R, Ghaidi F, Cox ME, Rennie PS. Short hairpin RNA knockdown of the androgen receptor attenuates ligand-independent activation and delays tumor progression. Cancer Res 2006;66:10613-10620.

35. Ke N, Zhou D, Chatterton JE, Liu G, Chionis J, Zhang J, et al. A new inducible RNAi xenograft model for assessing the staged tumor response to mTOR silencing. Exp Cell Res 2006;312:2726-2734.

36. Li L, Lin X, Staver M, Shoemaker A, Semizarov D, Fesik SW, et al. Evaluating hypoxia-inducible factor-1alpha as a cancer therapeutic target via inducible RNA interference in vivo. Cancer Res 2005;65:7249-7258.

37. Taulli R, Scuoppo C, Bersani F, Accornero P, Forni PE, Miretti S, et al. Validation of met as a therapeutic target in alveolar and embryonal rhabdomyosarcoma. Cancer Res 2006;66:4742-4749.

38. Hannon G, Rossi J. Unlocking the potential of the human genome with RNA interference. Nature 2004;431:371-378. 
39. Chan HM, Narita M, Lowe SW, Livingston DM. The p400 E1A-associated protein is a novel component of the p53 --> p21 senescence pathway. Genes Dev 2005;19:196-201.

40. Kubicka S, Trautwein C, Niehof M, Manns M. Target gene modulation in hepatocellular carcinomas by decreased DNA-binding of p53 mutations. Hepatology 1997;25:867-873.

41. Rottbauer W, Saurin AJ, Lickert H, Shen X, Burns CG, Wo ZG, et al. Reptin and pontin antagonistically regulate heart growth in zebrafish embryos. Cell 2002;111:661-672.

42. Feng Y, Lee N, Fearon ER. TIP49 regulates beta-catenin-mediated neoplastic transformation and T-cell factor target gene induction via effects on chromatin remodeling. Cancer Res 2003;63:8726-8734. 
Table 1. Primers for construction of plasmids expressing shRNAs.

\begin{tabular}{|l|l|}
\hline $\begin{array}{l}\text { Luciferase, } \\
\text { GL2-sense }\end{array}$ & $\begin{array}{l}\text { 5'-cgcgtcccCACGTACGCGGAATACTTCGAttcaagagaTCGAAGTATTCC } \\
\text { GCGTACGTGttttggaaat-3' }\end{array}$ \\
\hline $\begin{array}{l}\text { Luciferase, } \\
\text { GL2 } \\
\text { antisense }\end{array}$ & $\begin{array}{l}\text { 5'-cgatttccaaaaCACGTACGCGGAATACTTCGAtctcttgaaTCGAAGTATT } \\
\text { CCGCGTACGTGgggga-3' }\end{array}$ \\
\hline $\begin{array}{l}\text { Reptin, } \\
\text { R2-sense }\end{array}$ & $\begin{array}{l}\text { 5'-cgcgtcccGAAGATGTGGAGATGAGTGAGttcaagagaCTCACTCATCTC } \\
\text { CACATCTTCttttggaaat-3' }\end{array}$ \\
\hline $\begin{array}{l}\text { Reptin, } \\
\text { R2- } \\
\text { antisense }\end{array}$ & $\begin{array}{l}\text { 5'-cgatttccaaaaaGAAGATGTGGAGATGAGTGAGtctcttgaaCTCACTCATC } \\
\text { TCCACATCTTCgggga-3' }\end{array}$ \\
\hline
\end{tabular}

Capital letters indicate the targeting sequences. 
Table 2. Primers for PCR

\begin{tabular}{|c|c|}
\hline Gene & Primers sequence \\
\hline $\mathrm{Bad}$ & $\begin{array}{l}\text { U : 5' CCC AAC CTC TGG GCA GCA C 3' } \\
\text { L : 5' CGA GGA AGT CCC TTC TTA AAG GAG T 3' }\end{array}$ \\
\hline Bak1 & $\begin{array}{l}\text { U : 5’ CAA GAT TGC CAC CAG CCT GTT 3’' } \\
\text { L : 5’ AGG CCA TGC TGG TAG ACG TGT A 3', }\end{array}$ \\
\hline Reptin & $\begin{array}{l}\text { U : 5’ GCA ACC GTT ACA GCC ACA AC 3' } \\
\text { L : 5' CCG ATT CGC TCA ATC CTT GTT AC 3' }\end{array}$ \\
\hline$\beta$-actin & $\begin{array}{l}\text { U : 5’ GGA GGA GCT GGA AGC AGC C 3' } \\
\text { L : 5’ GCT GTG CTA CGT CGC CCT G 3' }\end{array}$ \\
\hline RLP0 & $\begin{array}{l}\text { U : 5’GGC GAC CTG GAA GTC CAA CT 3' } \\
\text { L : 5' CCA TCA GCA CCA CAG CCT TC 3' }\end{array}$ \\
\hline
\end{tabular}




\section{LEGENDS OF FIGURES}

Figure 1. Expression of a siRNA-resistant Reptin rescues the cell growth phenotype

$A$, Schematic representation of the Flag-tagged Reptin cDNA sequences. The Reptin-siRNA (R2) targeted sequence is indicated by capital letters. Silent mutations introduced are indicated by bold/italic letters (WT : wild type, Res : resistant). $B$, HuH7 cells transduced with a siR2-resistant Flag-tagged Reptin were transiently transfected with the indicated siRNAs or left non transfected (NT). Reptin expression was analyzed by Western blot after 4 or 6 days. Arrows on the left indicate the migration of Flag-tagged Reptin (Flag-R) and endogenous Reptin (R). The blot was rehybridized with an antibody to $\beta$-actin (lower part). $C$, Quantitative analysis. Cells were treated as in (a). Signals were quantified as described in the Materials and Methods section. Flag-tagged Reptin and endogenous Reptin were measured together and the results were normalized according to the actin value. Results from nontransfected cells were set at $100 \%$. Results are the mean \pm 1 SD of 3 separate experiments. $D$, HuH7 cells transduced with a siR2-resistant Flag-tagged Reptin were transiently transfected with the indicated siRNAs. Cell numbers were monitored at the indicated time points by counting in a Coulter counter. Data were normalized on the number of cells at Day 1 (set at 100) and are the mean of 3 separate experiments conducted in duplicate \pm SD. Transfection with siR1 significantly decreased cell numbers at Day $5(p=0.01)$ and Day $6(p=0.004)$.

\section{Figure 2. GFP and Reptin expression in GL2 and R2 cell lines after treatment with Dox.}

$A$, GL2 and R2 cell lines were exposed during 72 hours to the indicated concentrations of Dox. The percentage of GFP-positive cells was quantified by flow cytometry. $B$, Expression of Reptin transcripts. Seventy-two hours after Dox treatment $(0.016 \mu \mathrm{g} / \mathrm{ml})$ or not, total RNA was extracted and gene expression was measured with real time RT-PCR. The results were normalized on the basis of the expression of the RLP0 gene and on the levels of results 
obtained in the GL2 cell line not treated with Dox. The graph shows the mean \pm SEM of 3 independent experiments $(\mathrm{p}=0.001$ by ANOVA). $C$, Dose responsiveness of Dox-inducible R2 shRNA. Seventy-two hours after Dox treatment, cells were processed for western blot with anti-Reptin and anti- $\beta$-actin antibodies. $D$, Kinetics of Reptin expression. Cells were harvested just before Dox treatment $(0.016 \mu \mathrm{g} / \mathrm{ml})$ (Time 0) and then at indicated time points. Western blot of whole-cell extracts were performed with anti-Reptin and anti- $\beta$-actin antibodies. The signals were quantified with the Odyssey software and results were normalized on the basis of the expression of the $\beta$-actin gene and on the levels of corresponding cell line not treated with Dox. The graph shows the mean \pm SD of 2 to 4 independent experiments except for NT (non-transfected cells) where a single experiment was performed.

\section{Figure 3. Effect of Dox treatment on GL2 and R2 cell lines.}

$A$, HuH7 cell growth was measured with a Coulter counter at various times after Dox treatment $(0.016 \mu \mathrm{g} / \mathrm{ml})$. The results are the means \pm SEM of 3 experiments conducted in duplicate ( $\mathrm{p}<0.0001$ by ANOVA). Standard deviations are not shown for clarity, but were always below $15 \%$ of the mean. $B$, same experiment conducted with Hep3B cells $(\mathrm{n}=3$, $\mathrm{p}<0.0001$ by ANOVA). $C$, Six days after Dox treatment $(0.016 \mu \mathrm{g} / \mathrm{ml}), \mathrm{HuH} 7$ cells were harvested and caspase 3 activity was measured with a colorimetric substrate. The results are expressed with respect to the values found in GL2-Dox cells and are the mean \pm SD of 3 experiments in duplicate ( $\mathrm{p}<0.001$ by ANOVA). $D$, Six days after Dox treatment, senescence was assessed by measuring acid $\beta$-galactosidase activity ( $\beta$-gal) and staining DNA with DAPI.

\section{Figure 4. Effect of Dox treatment on tumor growth.}


A, HuH7 cells harboring the R2 or GL2 shRNAs were injected subcutaneously into NODSCID immunocompromised mice. When tumor volume reached $250 \mathrm{~mm}^{3}$, Dox $(2 \mathrm{mg} / \mathrm{ml})$, or sucrose, was administered in the drinking water. The results are expressed as the mean tumor volumes \pm SEM of 5 to 9 mice in each group ( $\mathrm{p}<0.0001$, Two-way ANOVA). The apparent decrease in volume in R2-Dox tumors between Days 20 and 25 is because a single animal with a large tumor had to be sacrificed in between these 2 days. $B$, A similar experiment was performed with Hep3B cells carrying R2 or GL2 shRNAs. Animals were sacrificed when tumor volume reached $2000 \mathrm{~mm}^{3}$. The results are expressed as the mean tumor volumes \pm SEM of 5 to 7 mice in each group ( $p<0.0001$, Two-way ANOVA). The inset shows part of the growth curves of two R2+Dox tumors that became undetectable upon repeated measurements. $C$, Immunostaining for Reptin in explanted $\mathrm{HuH7}$ tumors. A representative image from one tumor in each group is shown.

\section{Figure 5. Mechanisms of anti-tumor effects in vivo}

$A$, The R2 and GL2 cell lines were injected subcutaneously into NOG mice ( $\mathrm{n}=5$ in each group). When tumor volume reached $250 \mathrm{~mm} 3$, Dox $(2 \mathrm{mg} / \mathrm{mL})$, or sucrose, was administered in the drinking water. $B$, Human Reptin mRNA levels in explanted tumors. The results are expressed relative to the levels of the $\beta$-actin transcripts and are the mean \pm SD of 3 tumors. C, Explanted tumors were analyzed for Reptin and Ki67 expression by immunostaining. Senescence was assessed by measuring acid $\beta$-galactosidase activity ( $\beta$-gal) and staining DNA with DAPI. A representative image from one tumor in each group is shown. The bar indicates $500 \mu \mathrm{m}$ for Reptin, $200 \mu \mathrm{M}$ for Ki67, $40 \mu \mathrm{m}$ for $\beta$-gal and $20 \mu \mathrm{m}$ for DAPI. Arrows indicate numerous cells with characteristic senescence-associated heterochromatin foci in the R2+Dox group. D, Quantification of Ki67 labeling. Groups significantly differed using ANOVA (p = 0.0038). E, Expression of the mRNA levels of Bad and Bak in explanted 
tumors. The results are expressed relative to the levels of the $\beta$-actin transcripts and are the mean \pm SD of 3 tumors. No differences were statistically significant. 
A

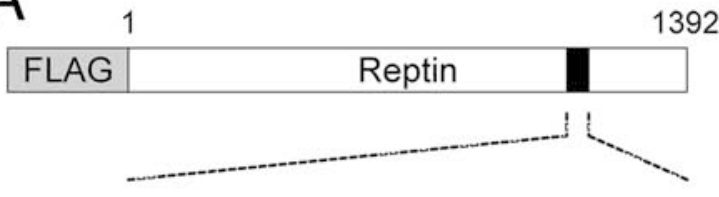

$\begin{array}{llllllllll}\text { E } & \text { E } & \text { D } & \text { V } & \text { E } & \text { M } & \text { S } & \text { E } & \text { D }\end{array}$

WT gaa GAA GAT GTG GAG ATG AGT GAG gac

Res gaa GGG GAC GTC GAA ATG AGT GAG gac

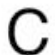

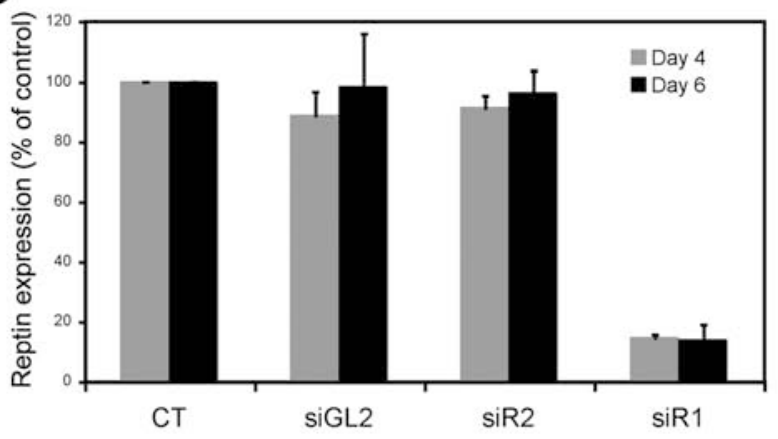

B

Day 4

Day 6

NT GL2 R2 R1 NT GL2 R2 R1

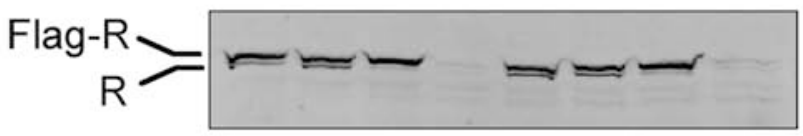

Actin

D

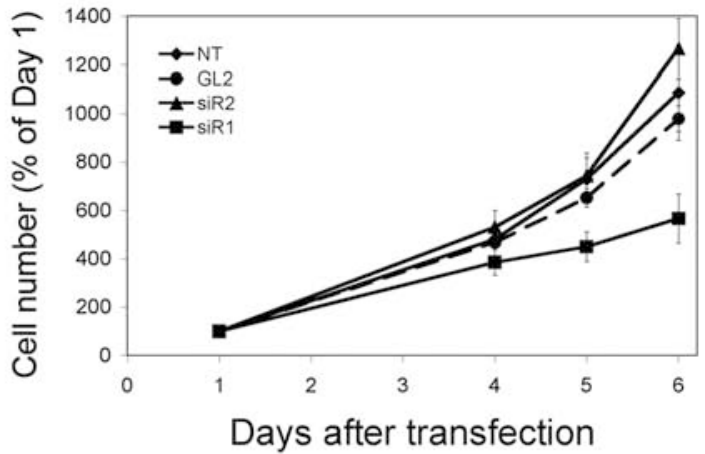




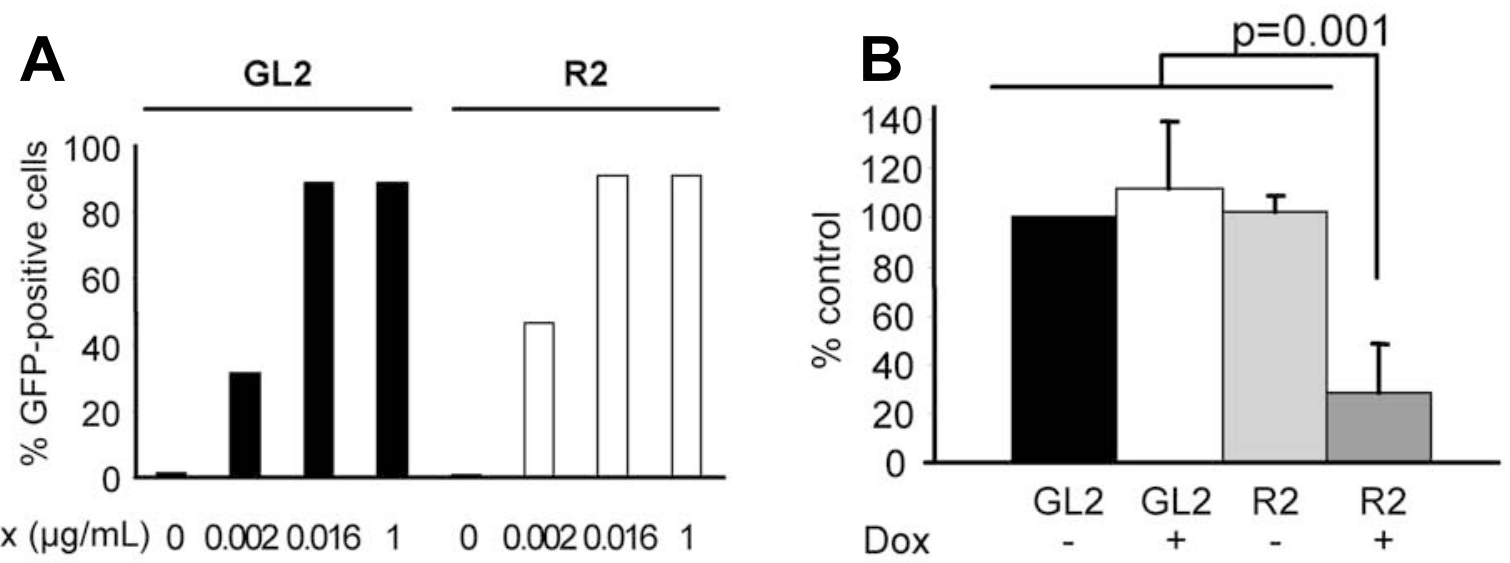

$\operatorname{Dox}(\mu \mathrm{g} / \mathrm{mL}) \quad 0 \quad 0.0020 .0161100 .0020 .0161$

C

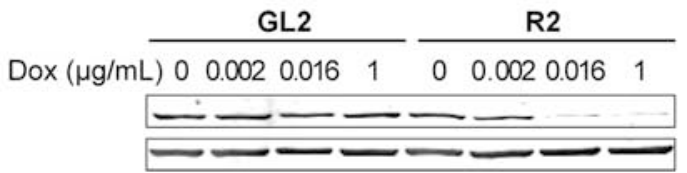

Reptin $\beta$-actin

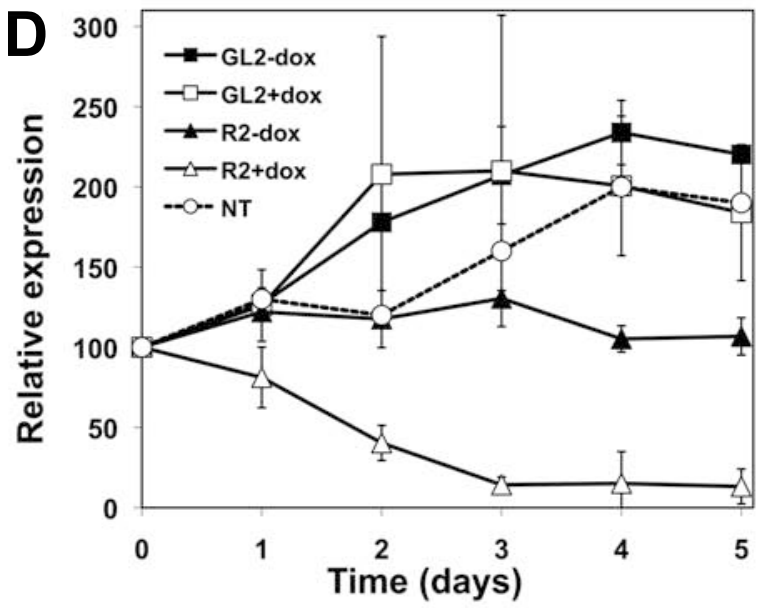




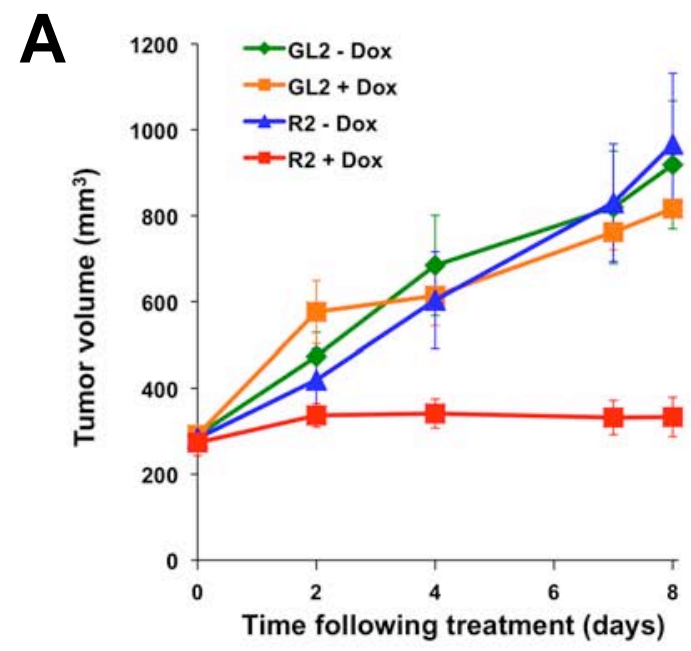

B

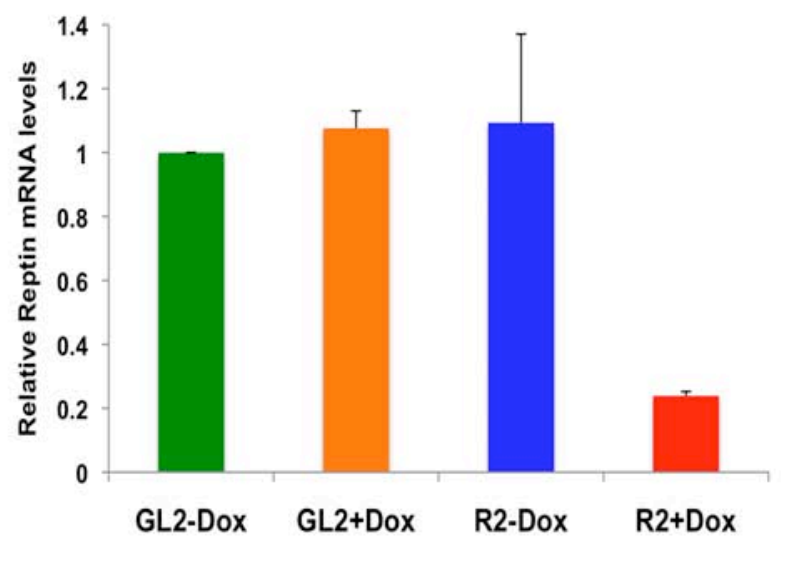

C GL2-Dox
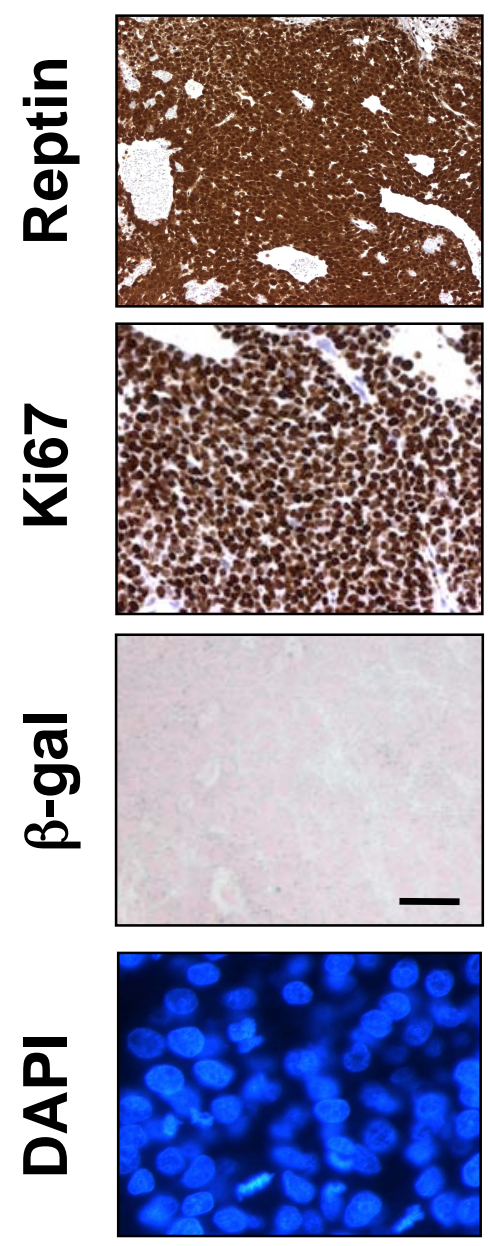

D

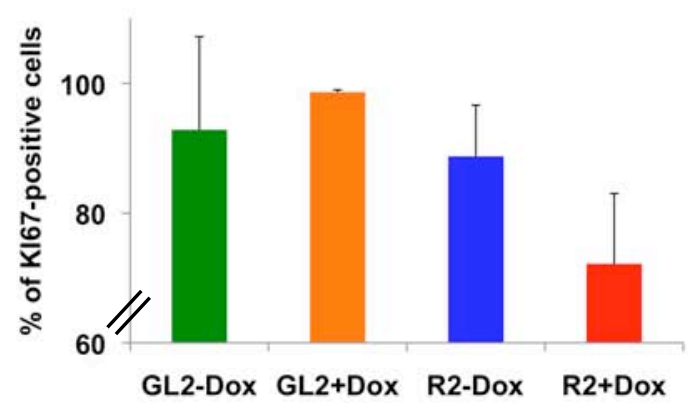

\section{GL2+Dox}
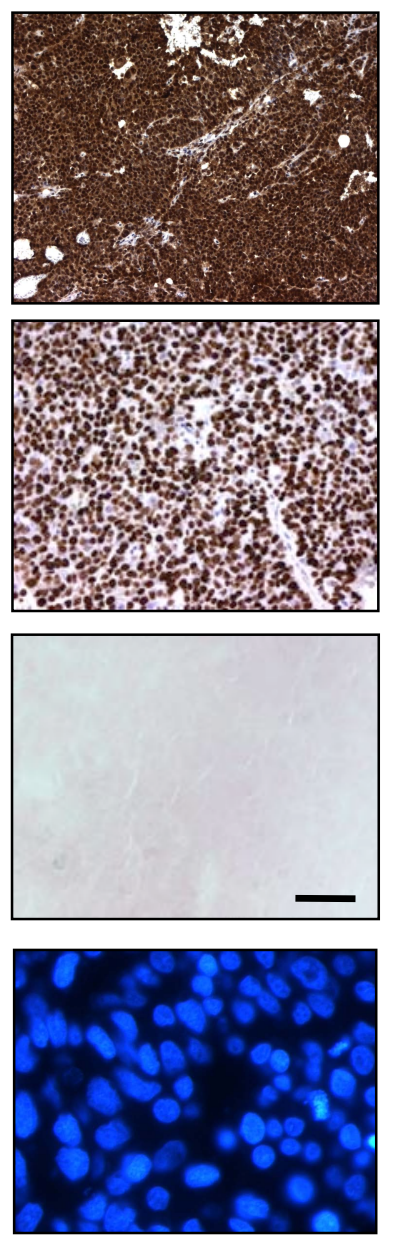

E

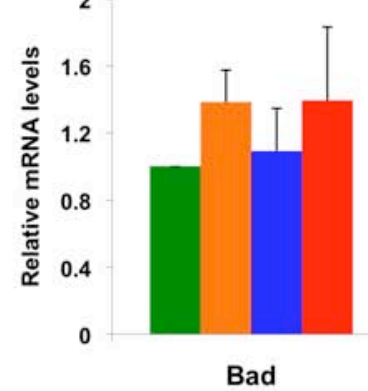

R2+Dox
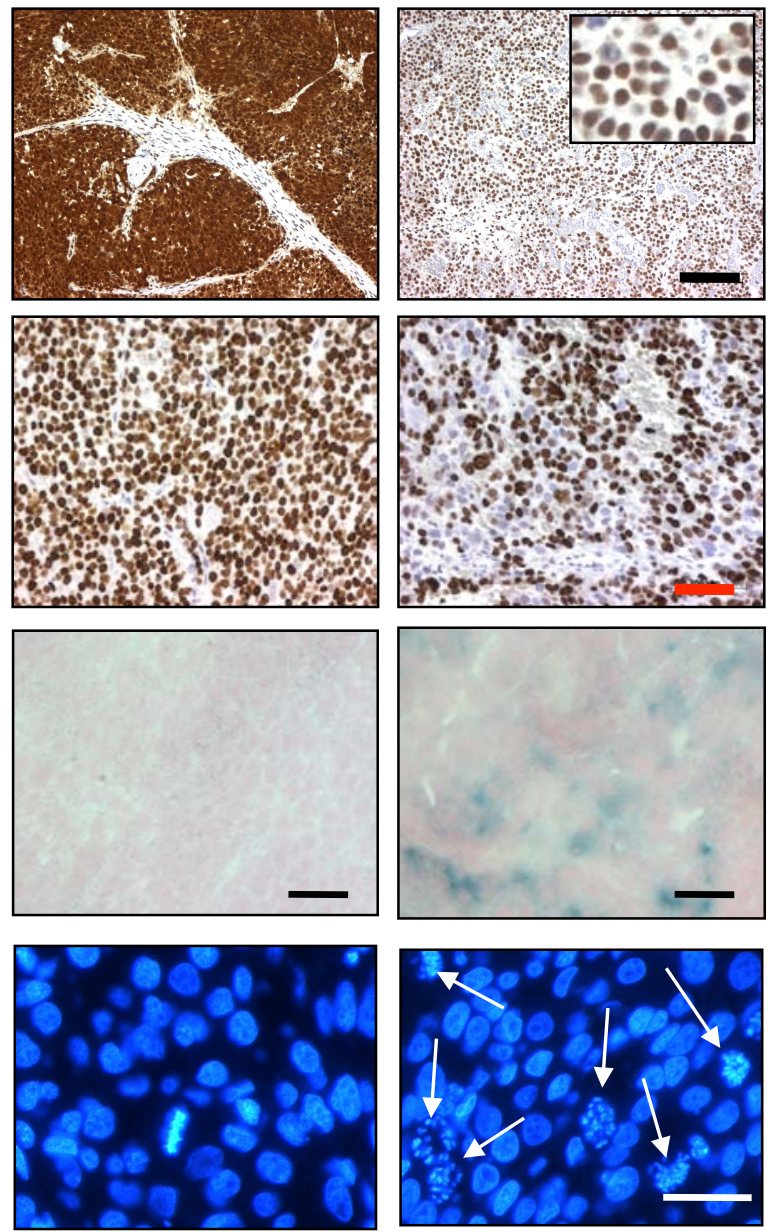

- GL2-Dox

= GL2+Dox

- R2-Dox

= R2+Dox

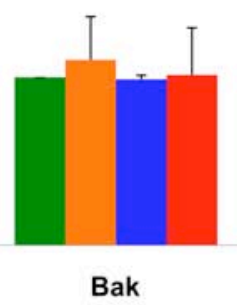



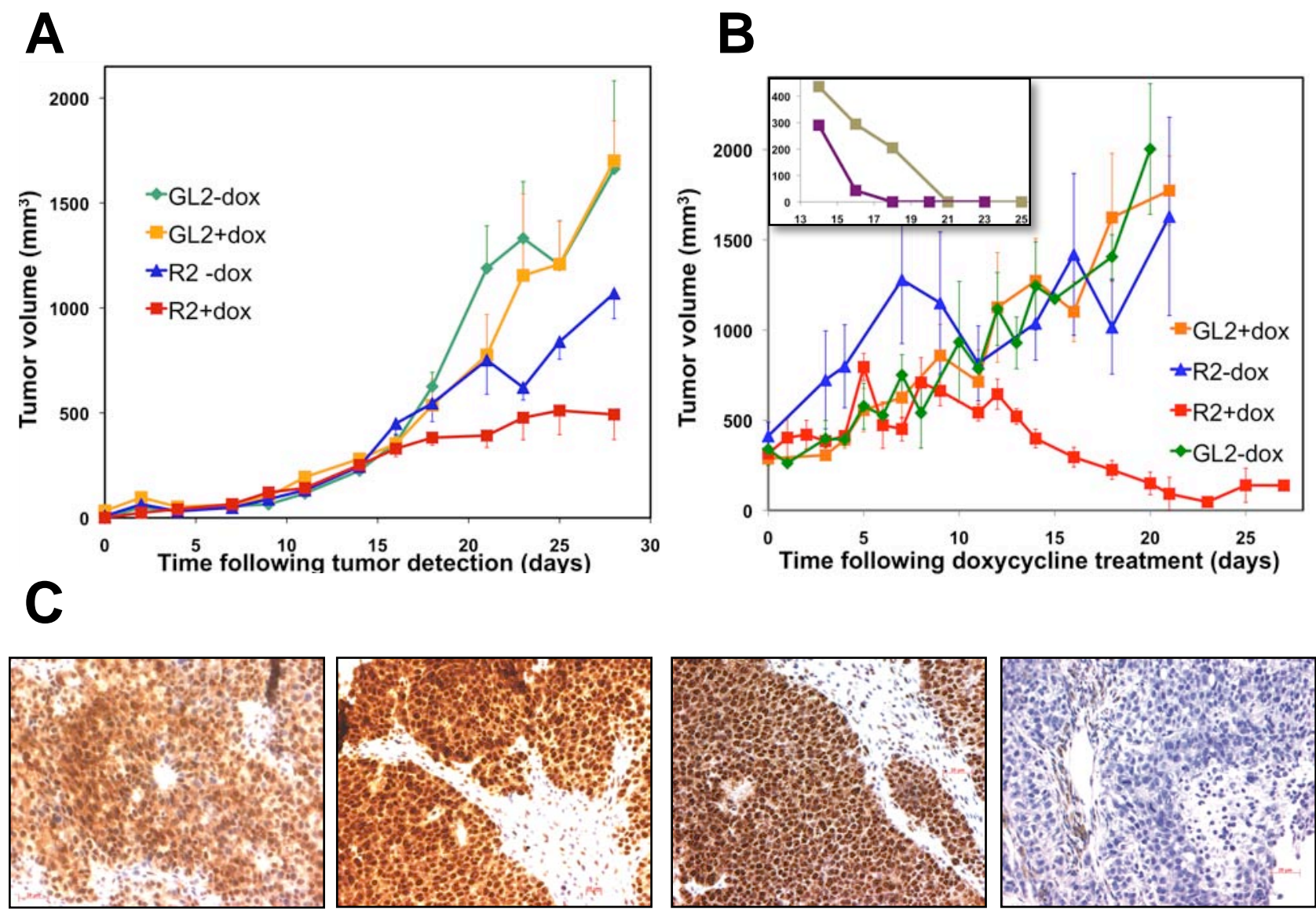

GL2 - Dox

GL2 + Dox

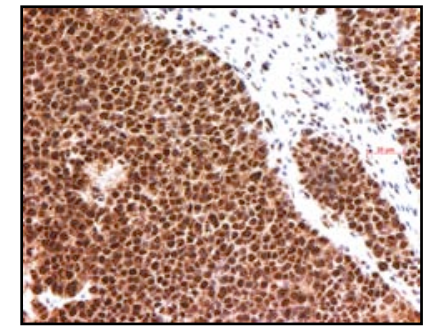

R2 - Dox

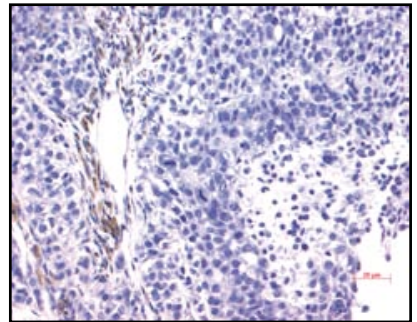

R2 + Dox 

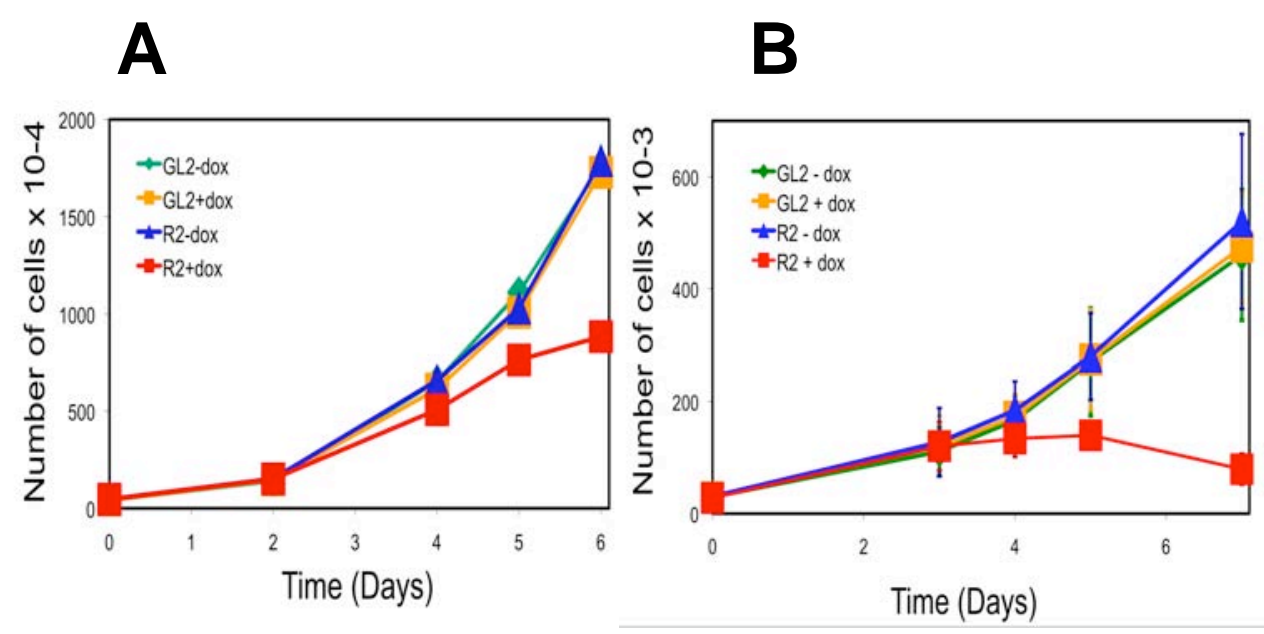

C

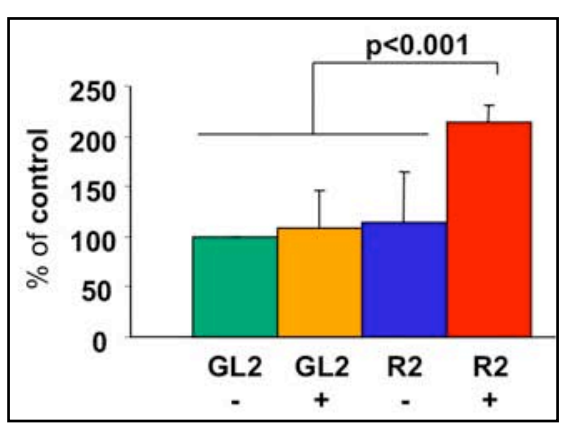

Time (Days)
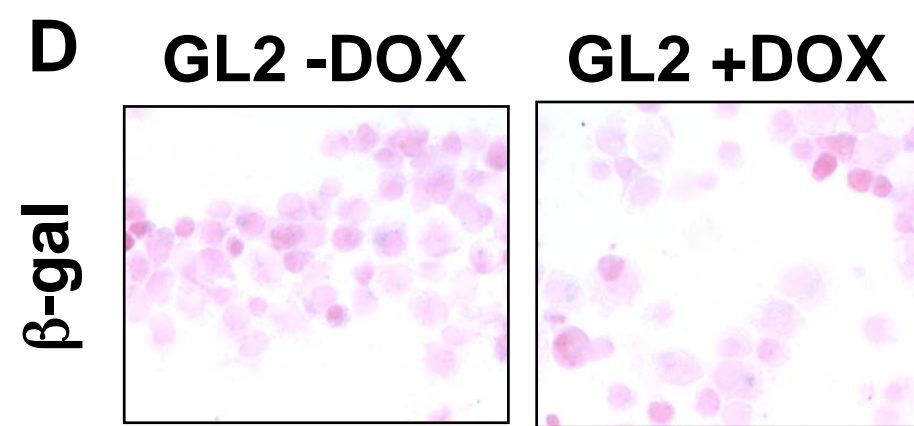

R2 -DOX

R2 +DOX
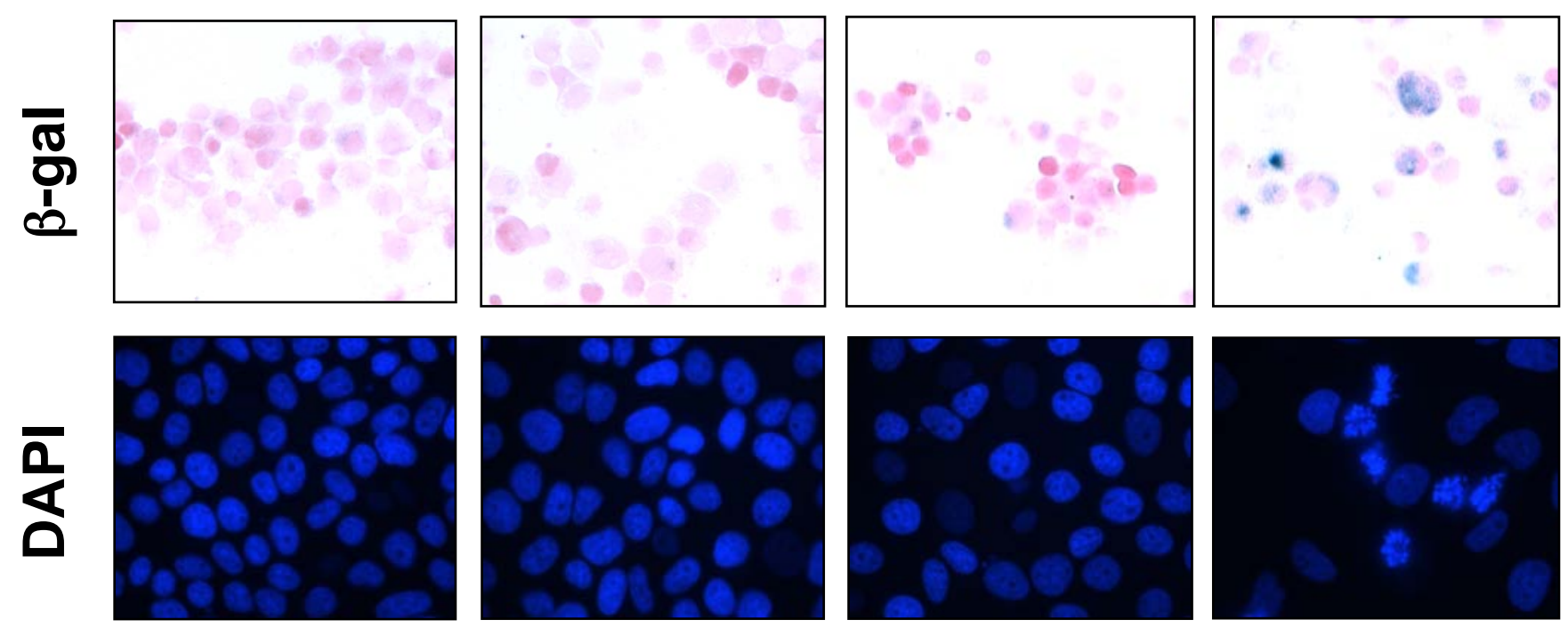